\title{
EVALUATION OF THE THROUGHFALL AND STEMFLOW NUTRIENT CONTENTS IN MIXED AND PURE PLANTATIONS OF Acacia mangium, Pseudosamenea guachapele AND Eucalyptus grandis ${ }^{1}$
}

\author{
Fabiano de Carvalho Balieiro ${ }^{2}$, Avílio Antônio Franco ${ }^{3}$, Renildes Lúcio Ferreira Fontes ${ }^{4}$, Luiz Eduardo \\ Dias $^{4}$, Eduardo Francia Carneiro Campello ${ }^{3}$ e Sérgio Miana de Faria ${ }^{3}$
}

\begin{abstract}
The interception of the rainfall by the forest canopy has great relevance to the nutrient geochemistry cycle in low fertility tropical soils under native or cultivated forests. However, little is known about the modification of the rainfall water quality and hydrological balance after interception by the canopies of eucalyptus under pure and mixed plantations with leguminous species, in Brazil. Samples of rainfall (RF), throughfall (TF) and stemflow (SF) were collected and analyzed in pure plantations of mangium (nitrogen fixing tree -NFT), guachapele (NFT) and eucalyptus (non-nitrogen fixing tree-NNFT) and in a mixed stand of guachapele and eucalyptus in Seropédica, State of Rio de Janeiro, Brazil. Nine stemflow collectors (in selected trees) and nine pluviometers were randomly disposed under each stand and three pluviometers were used to measure the incident rainfall during 5.5 months. Mangium conveyed $33.4 \%$ of the total rainfall for its stem. An estimative based on corrections for the average annual precipitation $(1213 \mathrm{~mm})$ indicated that the rainfall's contribution to the nutrient input $\left(\mathrm{kg} \mathrm{ha}^{-1}\right)$ was about $8.42 ; 0.95 ; 19.04 ; 6.74 ; 4.72$ and $8.71 \mathrm{~kg} \mathrm{ha}^{-1}$ of $\mathrm{N}-\mathrm{NH}_{4}^{+}, \mathrm{P}, \mathrm{K}^{+}$, $\mathrm{Ca}^{+2}, \mathrm{Mg}^{+2}$ and $\mathrm{Na}^{+}$, respectively. Throughfall provided the largest contributions compared to the stemflow nutrient input. The largest inputs of $\mathrm{N}-\mathrm{NH}_{4}^{+}\left(15.03 \mathrm{~kg} \mathrm{ha}^{-1}\right)$ and $\mathrm{K}^{+}\left(179.43 \mathrm{~kg} \mathrm{ha}^{-1}\right)$ were observed under the guachapele crown. Large amounts of $\mathrm{Na}^{+}$denote a high influence of the sea. Mangium was the most adapted species to water competitiveness. Comparatively to pure stand of eucalyptus, the mixed plantation intensifies the $\mathrm{N}, \mathrm{Ca}$ and $\mathrm{Mg}$ leaching by the canopy, while the inputs of $\mathrm{K}$ and $\mathrm{P}$ were lower under these plantations.
\end{abstract}

Keywords: Nutrient cycling, leguminous tree, atmospheric nutrient input and mixed forest plantation.

\section{AVALIACÃO DO CONTEÚDO DE NUTRIENTES NA ÁGUA DE PRECIPITAÇÃO INTERNA E DE ESCOAMENTO PELO TRONCO EM PLANTIOS DE Acacia mangium, Pseudosamenea guachapele E Eucalyptus grandis}

\begin{abstract}
RESUMO - A interceptação da chuva pela copa das florestas tem grande relevância no ciclo biogeoquímico de nutrientes nos solos de baixa fertilidade sob florestas nativas e plantadas. Entretanto, pouco se sabe sobre as modificações na qualidade dessa água e no balanço hidrológico após a interceptação pela copa do eucalipto sob condições de plantios puros e mistos com leguminosas, no Brasil. Amostras de água de chuva (RF), de precipitação interna $(T F)$ e de escoamento pelo tronco $(S F)$, foram coletadas e analisadas quimicamente em plantios puros de mangium (espécie fixadora de nitrogênio atmosférico - EFN), guachapele (EFN) $e$ eucalipto (espécie não fixadora de nitrogênio - ENFN) e consorciados com guachapele e eucalipto, em Seropédica, Rio de Janeiro. Nove coletores de escoamento pelo tronco (colocados em árvores), nove pluviometros posicionados
\end{abstract}

\footnotetext{
${ }^{1}$ Recebido em 09.06.2006 e aceito para publicação em 02.03.2007.

${ }^{2}$ Embrapa Solos, Rua Jardim Botânico, 1024, Jardim Botânico, 22460-000 Rio de Janeiro, RJ. E-mail: <balieiro@cnps.embrapa.br>.

${ }^{3}$ Embrapa Agrobiologia, Br 465, km 7, 23890-000 Seropédica, RJ. Email: <avilio@cnpab.embrapa.br>, <campello@cnpab.embrapa.br>, <sdefaria@cnpab.embrapa.br>.

${ }^{4}$ Universidade Federal de Viçosa, Av. PH Rolfs, s/n, Departamento de Solos, Campus da Universidade Federal de Viçosa, 36570-000 Viçosa, MG. E-mail: <renildes@ufv.br>, <ledias@ufv.br>.
} 
ao acaso nos plantios e três fora da influência deles foram utilizados no monitoramento durante 5,5 meses. A mangium direcionou 33,4\% do total precipitado para o seu tronco. Uma estimativa baseada na correção da média anual precipitada na área $(1.213 \mathrm{~mm})$ indicou uma contribuição no aporte de nutrientes $(\mathrm{kg}$ $\mathrm{ha}^{-1}$ ) de 8,42; 0,95; 19,04; 6,74; 4,72; e 8,71 $\mathrm{kg} \mathrm{ha}^{-1}$ dos elementos $\mathrm{N}-\mathrm{NH}_{4}^{+}, \mathrm{P}_{\mathrm{O}} \mathrm{K}^{+} \mathrm{Ca}^{+2}, \mathrm{Mg}^{+2}$ and $\mathrm{Na}^{+}$, respectivamente. A precipitação interna participou com a maior parte da contribuição, em comparação com o escoamento pelo tronco. Os maiores aportes de $\mathrm{N}-\mathrm{NH}_{4}^{+}\left(15,03 \mathrm{~kg} \mathrm{ha}^{-1}\right)$ e $\mathrm{K}^{+}\left(179,43 \mathrm{~kg} \mathrm{ha}^{-1}\right)$ foram observados sob as copas de guachapele em plantio puro. Elevada quantidade de $\mathrm{Na}^{+}$denota influencia do mar próximo à área experimental. A mangium foi a espécie adaptada à competição por água. Comparativamente ao plantio puro de eucalipto, o plantio misto intensificou a lixiviação de $\mathrm{N}$, Ca e Mg da copa, enquanto o de $K$ e o $P$ aportaram em menores quantidades nesse plantio.

Palavras-chave: Ciclagem de nutrientes, leguminosas arbóreas, aporte atmosférico de nutrientes e plantio florestal misto.

\section{INTRODUCTION}

$\mathrm{N}$ input through biological nitrogen fixation (BNF) and consequently through the litterfall, decomposing roots and nodules or rhizodeposition from leguminous plants may result in significant economic and ecological advantages in the implementation of mixed forests. Recent results showed that intercropping of eucalyptus with tree legumes is not detrimental to timber yield but potentially advantageous to increasing soil $\mathrm{N}$ availability for eucalyptus and C stocks (BINKLEY et al., 1992; RESH, 2002; BALIEIRO et al., 2002; FORRESTER et al., 2006).

Rainfall interception by the forest canopy has great relevance to the nutrient geochemistry cycle in tropical forests and plantations, with prevalently acid soils and low natural soil fertility (STANFORD Jr., 1987; LACLAU et al., 2003). The interception, besides involving evaporative losses and consumption of water from shoots, is responsible for changes in the quality of the water that reaches the soil. These alterations are mainly a result of two factors: the washing of the elements deposited on the foliage (dry deposition as dust) and due to changes that occur directly in the tree canopy through nutrient leaching from shoots and/or by the direct nutrient uptake by the leaves (uptake by stomata or hydrophilic pores within the cuticle) (KRAMER and BOYER, 1995; MARSHNER, 1995).

Several factors such as canopy architecture, leaf area index, density and structure of plantation, rainfall intensity and raindrop size can be responsible for differences in the magnitude of this interaction "rainfallforest"'(OPAKUNLE, 1989; LEITE et al., 1999; CALDER, 1998; ARCOVAet al., 2003), whereas geographical location (ANDRADE et al., 1995; LACLAU et al., 2003), proximity to industrial zones, urban centers or marine areas (GOLLEY et al., 1978; LACLAU et al., 2003) and burning occurrence (LIMA, 1979) are the others related to water composition.

Fast growing multipurpose leguminous trees such as Acacia mangium, A. angustissima, A. auriculformes, A. holocerisea and Pseudosamanea gucahapele were introduced in Brazil. They form symbiosis with rhizobia and mycorrhizal fungi and some of them are well adapted to acidic soils, with tolerance characteristics that stimulated their use in rehabilitation of degraded soils (NATIONAL..., 1983; FRANCO and FARIA, 1997; BROCKWELL et al., 2005). However, little is known about the modification of the rainfall water nutrient contents and hydrological balance after interception by canopies of adult trees of these species in Brazil.

The objective of this study was to evaluate the contribution of rainfall water as a source of nutrients after interception by the canopies of pure stands of Acacia mangium Willd., Pseudosamanea guachapele (Kunth) Harms and Eucalyptus grandis Hill ex Maiden and a mixed stand of $P$. guachapele and E. grandis.

\section{MATERIALS AND METHODS}

\subsection{Description of the study site}

The experiment was carried out in the Municipality of Seropédica (22 $46^{\prime}$ S and $43^{\circ} 41^{\prime}$ W), State of Rio de Janeiro, Brazil. The climate is classified as type AW according to the Köppen System (McKNIGHT, 1996), although AW designates a savanna climate, a vegetation type that does not occur in the area, probably due to the proximity of the coastal zone and inexistence of a defined dry season. For the last ten years the mean annual rainfall has been $1.250 \mathrm{~mm}$, with temperature 
ranging from a minimum of $15^{\circ} \mathrm{C}$ (June-July) to a maximum of $32^{\circ} \mathrm{C}$ (January-March). The air humidity reaches an annual average of $73 \%$ (MATTOS et al., 1998).

The experiment was located on a Planosol (EMBRAPA, 1999), characterized by a superficial sandytexture horizon (that could reach $1.8 \mathrm{~m}$ depth), a subsuperficial gley horizon with "loamier" texture, low cation exchange capacity (CEC), low fertility and organic matter contents. Under pure plantation of Acacia mangium a transition from Planosol to Argissol (EMBRAPA, 1999) was observed. Slope values ranged from $2 \%$ to $5 \%$. The area was used previously as pasture, with occasional fertilization. Chemical analyses were carried out using soil samples $(0-20 \mathrm{~cm})$ taken before the seedling transplantation, (Table 1). No fertilization was carried out prior to sampling.

\subsection{Seedlings production and planting in the field}

The seedlings were produced with a substratum consisting of $60 \%$ organic matter, $20 \%$ clay, $10 \%$ sand and $10 \%$ rockphosphate $\left(24 \% \mathrm{P}_{2} \mathrm{O}_{5}\right)$. Seeds of $P$. guachapele (guachapele) and A. mangium (mangium) were inoculated with specific Rhyzobium strains (BR 6205 and BR 6821 for guachapele and BR 3609 and BR 3617 for mangium), whereas the inoculation with vesicular-arbuscular mycorrhizal fungi (Gigaspora margarita and Glomus clarum) was performed for all plant species. Eucalyptus grandis seedlings received $50 \mathrm{mg} / \mathrm{dm}^{3} \mathrm{NH}_{4}\left(\mathrm{SO}_{4}\right)_{2}$ in split applications during the seedling stage. Three-month old seedlings were transplanted in 1993 to the field, each receiving 100 $\mathrm{g}$ rockphosphate $\left(24 \% \mathrm{P}_{2} \mathrm{O}_{5}\right)$ and $10 \mathrm{~g}$ fritted trace elements (FTE BR-12). A total of $25 \mathrm{~g} / \mathrm{m}$ of ammonium sulphate was applied on topsoil of the eucalyptus plantation. Plants were spaced $3 \times 1 \mathrm{~m}$ and each stand had area of $2,500 \mathrm{~m}^{2}$.

Table 1 - Chemical characteristics of the soil sampled under each plantation (0-20 $\mathrm{cm}$ of deph)

Quadro 1 - Características do solo amostrado sob cada plantio ( 0 -20 $\mathrm{cm}$ de profundidade)

\begin{tabular}{lcccccc}
\hline \multirow{2}{*}{ Stand } & $\mathrm{PH}$ & \multicolumn{2}{c}{$\mathrm{Al}^{3+} \mathrm{Ca}^{2+}+\mathrm{Mg}^{2+}$} & & $\mathrm{P}$ & $\mathrm{K}$ \\
\cline { 3 - 4 } \cline { 6 - 7 } & & \multicolumn{2}{c}{$\mathrm{cmol}_{\mathrm{c}} / \mathrm{dm}^{3}$} & & \multicolumn{2}{c}{$\mathrm{mg} / \mathrm{dm}^{3}$} \\
\hline Guachapele & 5.5 & 0.1 & 1.5 & & 9.4 & 26.0 \\
Eucalyptus & 5.0 & 0.1 & 1.0 & & 20.4 & 14.0 \\
Mangium & 5.1 & 0.2 & 1.0 & & 11.2 & 16.0 \\
\hline
\end{tabular}

${ }^{1} \mathrm{pH}$ in water $(1: 2,5), \mathrm{Al}^{3+}, \mathrm{Ca}^{2+}$ and $\mathrm{Mg}^{2+}$ exchangeable: extracted with $\mathrm{KCl} 1 \mathrm{~mol}^{-\mathrm{L}^{-1}}$ and $\mathrm{P}$ and $\mathrm{K}$ - available, extracted with Mehlich-1.

\subsection{Sampling}

Precipitation, throughfall and stemflow were measured and collected daily every morning (8:00 a.m.) from January $1^{\text {st }}$ to June $15^{\text {th }}, 1998$.

Rainfall and throughfall, entering each stand, were collected by nine $15 \mathrm{~cm}$ diameter polyethylene funnels (REICHARDT, 1990) connected by tubes to two-liter polyethylene containers. Stemflow samples were collected by a special collector made with polyurethane foam (BALIEIRO et al., 2001) placed at breast height, directing the water to 54-liter polyethylene containers. No biocides were added to the collectors, but they were washed with chloric acid solution $3 \%$, followed by washing with distilled water. Nine trees (diameter at breast height near of those observed in the stands) of each species stand were monitored. Anylon screen was placed inside the funnels (pluviometers) to prevent contamination with debris that could affect the chemical composition of the collected water. The containers were cleaned periodically during the experiment to avoid the development of microorganisms in the water.

The collecting area of each pluviometer was $0.0177 \mathrm{~m}^{2}$. The rainfall (three pluviometers) and throughfall height (nine pluviometers per stand), in mm, was determined by the equation:

$$
\mathrm{y}(\mathrm{mm})=\mathrm{x} / 0.0177,
$$

where $\mathrm{x}$ is the volume (in liters) accumulated in each collector. The contribution of the stemflow was calculated by using the average volume (L) of three containers multiplied by 3.333 , the number of trees/ ha (considering $100 \%$ survival). Then, for each event (rain) and treatment, three replicates of both compartments (throughfall and stemflow water) were analyzed for nutrient contents. All the samples (rainfall, throughfall and stemflow) were characterized by their concentrations of $\mathrm{N}-\mathrm{NH}_{4}^{+}, \mathrm{P}, \mathrm{K}^{+}, \mathrm{Ca}^{+2}, \mathrm{Mg}^{+2}$ and $\mathrm{Na}^{+}$. Samples of each event were taken, $\mathrm{pH}$ determined and then stored in a freezer for further chemical analysis. Ammonium was determined by the salycilate method (KEMPERS and ZWEERS, 1986 modified by Passos et al., 1998), whereas $\mathrm{Na}^{+}$and $\mathrm{K}^{+}$by flame photometry from direct sample reading. Calcium and magnesium were determined by the atomic absorption method and phosphorus by colorimetry (DEFELIPO and RIBEIRO, 1986).

R. Árvore, Viçosa-MG, v.31, n.2, p.339-346, 2007 


\subsection{Statistical analysis}

The effect of throughfall and stemflow were evaluated using GLM (General Linear Models) considering the rainfall as covariate. Multiple comparisons tests and regression linear procedures were applied to data using the SAEG software Genetic and Statistic Analysis System, (EUCLYDES, 1983).

\section{RESULTS AND DISCUSSION}

The rainfall at the experimental site was $727 \mathrm{~mm}$ from January to June. The studied canopies- mangium, guachapele and eucalytus in pure stands or in mixed crop of guachapele and eucalytus - altered the incident rainfall $(\mathrm{P} \leq 0.01)$ (Figure 1$)$.

Only $52.2 \%$ of the incident rainfall in the mangium plantation reached the soil, whereas 78.7, 78.5 and 82.6\% reached the soil under guachapele, eucalyptus and the mixed crop, respectively. Values of precipitation loss due to canopy interception were estimated at 14.4, $11.9,15.6$ and $11.8 \%$ in the pure stands of mangium, guachapele and eucalyptus and in the mixed crop of guachapele and eucalyptus. Mangium canopy intercepted and led to its trunk more rainfall (33.4\%) than guachapele (9.4 and 5.9\%) and eucalyptus in pure and mixed stands (5.6\%) ( $\mathrm{P}=0.05)$ (Figure 2). Differences in stemflow patterns among plantations may be explained by the percentage of green leaves and height of their canopies, i.e., their architecture. With a higher leaf fresh biomass ( $7.1 \%$ of total aerial biomass) and taller canopy (10.40 $\mathrm{m}$ from top of the tree to the lowest live branch), mangium, in this experiment, collected the highest volume of water under rainfall ( $33.4 \%$ of the incident rainfall). An acute angle of lateral branches insertion could be considered an adaptive advantage of mangium to collect water. This capacity to collect water to its trunk may give to mangium an advantage when competing under water stress and/or low fertility conditions

In terms of quality, the rainfall analyzed in this experiment was more acidic $(\mathrm{pH}=4.3$, in average) than pure water in equilibrium with atmospheric $\mathrm{CO}_{2}(\mathrm{pH}$ =5.6). Water acidity decreased after crossing the canopy of all species, with guachapele presenting the strongest effect (reaching a value close to 6.0). This species has also been indicated for phytoremediation of sites contaminated with heavy metals, because it can immobilize (by phytostabilization) these metals by precipitation and complexation (KRÄMER, 2005).

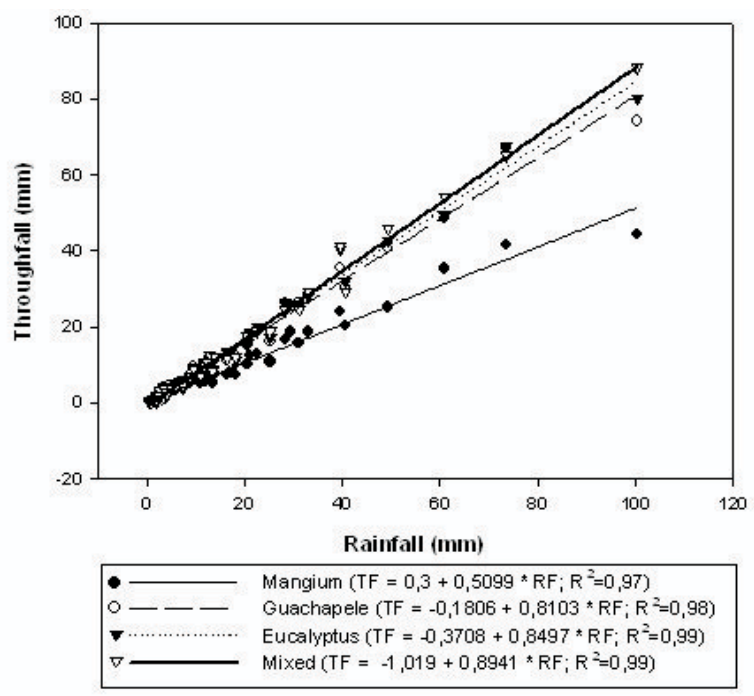

Figure 1 - Canopy flux of water throughfall $(\mathrm{mm}) v s$. rainfall $(\mathrm{mm})$ under pure and mixed forest plantations $(\mathrm{n}=58$ for throughfall studies).

Figura 1 - Fluxo de água de precipitação interna vs. incidente sob plantios florestais puros e mistos ( $n=58$ para precipitação interna).

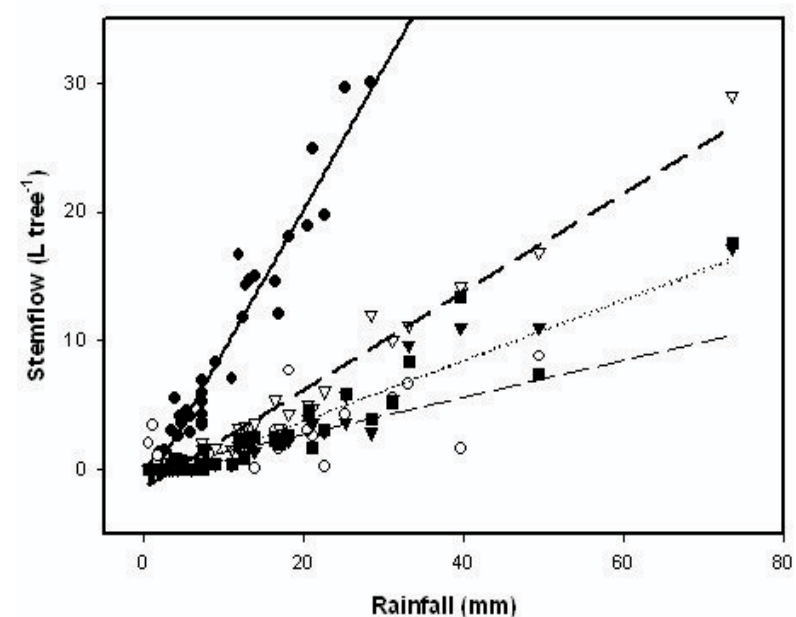

Figure 2 - Canopy flux of water stemflow $\left(\mathrm{L} \mathrm{tree}^{-1}\right) v s$. rainfall $(\mathrm{mm})$ under pure and mixed forest plantations $(\mathrm{n}=48$ events/rains for stemflow).

Figura 2 - Fluxo de água pela copa por meio do escoamento pelo trocno vs. precipitação incidente sob plantios florestais puros e mistos ( $n=48$ eventos/chuvas para o estudo de escoamento pelo tronco). 
The stemflow and the throughfall chemical analyses showed that the canopy of each species increased the concentration of nutrients $\left(\mathrm{N}-\mathrm{NH}_{4}^{+}, \mathrm{K}^{+}, \mathrm{Ca}^{+2}, \mathrm{Mg}^{+2}\right.$ and $\mathrm{Na}^{+}$) in throughfall and the same nutrients plus $\mathrm{P}$ in stemflow measurements (Table 2).

The experiment was conducted during six months ( $727 \mathrm{~mm})$, and then the yearly average rainfall was estimated $(1.213 \mathrm{~mm})$. Results indicated that contribution of the rainfall to nutrient input was about $8.42 ; 0.95$; 19.04; 6.74; 4.72 and 8.71 kg.ha ${ }^{-1}$ of N-NH4 ${ }^{+}, \mathrm{P}^{+} \mathrm{K}^{+}, \mathrm{Ca}^{+2}$, $\mathrm{Mg}^{+2}$ and $\mathrm{Na}^{+}$, respectively. Considering the canopies leaching/washing, the stemflow and throughfall nutrient depositions to soil were higher than from the incident rainfall (Table 3 ).

Compared to this work, Andrade et al. (1995) in Mogi-Guaçu, São Paulo State, reported N inputs (by rainfall) 1.6 times higher $\left(5.32 \mathrm{~kg} \mathrm{ha}^{-1} \cdot \mathrm{year}^{-1}\right)$ and similar quantities of $\mathrm{P}\left(1.20 \mathrm{~kg} \cdot \mathrm{ha}^{-1}\right.$.year $\left.{ }^{-1}\right)$ and about 5.3 $\mathrm{kg} \cdot \mathrm{ha}^{-1}$.year ${ }^{-1}$ of $\mathrm{K}$. The P input found $(0.95 \mathrm{~kg}$.ha${ }^{1}$. year $\left.^{-1}\right)$ is also 1.6 times higher than that reported by Golley et al. (1978) (0.6 kg.ha ${ }^{-1}$.year $\left.{ }^{-1}\right)$ in a Tropical Humid Forest in Panama.

In this work, the inputs of calcium from rainfall (6.74 kg.ha-1. year $\left.^{-1}\right)$ to soil were lower than that found by others authors (GOLLEY et al., 1978; LIMA, 1993; JORDAN, 1982). Similar quantities due to rainfall were detected by Andrade et al. (1995) (5.09 kg.ha ${ }^{-1} \cdot$ year $\left.^{-1}\right)$ in Rio de Janeiro (near the sea).

The concentration found for $\mathrm{Na}^{+}$can be explained by the proximity to the ocean $(30 \mathrm{~km})$. Higher values of sodium $\left(22 \mathrm{~kg} \cdot \mathrm{ha}^{-1} \cdot\right.$ year $\left.^{-1}\right)$ inputs were found in a forest closer to the sea in Rio de Janeiro (SILVA FILHO, 1985). The contribution of $\mathrm{K}^{+}$in the present experiment was higher than that found in the same district (3.91 kg.ha-1. year $^{-1}$ ) of this study (CARVALHO, 1992). Dry (ash) deposition on leaves could increase as a result of a frequent occurrence of burnings.

The interception of precipitation by canopies of all species added $\mathrm{N}-\mathrm{NH}_{4}^{+}, \mathrm{P}, \mathrm{K}^{+}, \mathrm{Ca}^{+2}, \mathrm{Mg}^{+2}$ and $\mathrm{Na}^{+}$ to the rainfall in both the throughfall and stemflow water (Table 2). Acacia mangium showed lower contribution. The throughfall contribution decreased with the increase in stemflow volume of each species.

Differences in nutrient inputs for each plantation could be attributed to their nutrient status, as considered by Andrade et al. (1995). In the present experiment, higher quantities of $\mathrm{Ca}^{+2}$ were added by stemflow in eucalyptus than by other species, and the $\mathrm{N}-\mathrm{NH}_{4}{ }^{+}, \mathrm{P}$ and $\mathrm{Na}^{+}$contents in mangium stemflow were higher than from all other species. The higher values of total nutrient added by mangium was due to the high capacity of this species to collect and to direct water to its trunk.

Table 2 - Concentration $\left(\mathrm{mg} \mathrm{L}^{-1}\right)$ of $\mathrm{N}-\mathrm{NH}_{4}^{+}, \mathrm{P}, \mathrm{K}^{+}, \mathrm{Ca}^{+2}, \mathrm{Mg}^{+2}$ and $\mathrm{Na}^{+}$in rainfall (RF), throughfall (TF) and stemflow collected water under each plantation

Quadro 2 - Concentração $\left(\mathrm{mg} \mathrm{L}^{-1}\right)$ de $\mathrm{N}-\mathrm{NH}_{4}^{+}, \mathrm{P}, \mathrm{K}^{+}, \mathrm{Ca}^{+2}, \mathrm{Mg}^{+2}$ e $\mathrm{Na}^{+}$na água de chuva (RF), de precipitação interna (TF) e que escoa pelo tronco, coletada sob cada plantio

\begin{tabular}{|c|c|c|c|c|c|c|}
\hline Species/stand & $\mathrm{N}-\mathrm{NH}_{4}^{+}$ & $\mathrm{P}$ & $\mathrm{K}^{+}$ & $\mathrm{Ca}^{+2}$ & $\mathrm{Mg}^{+2}$ & $\mathrm{Na}^{+2}$ \\
\hline & \multicolumn{6}{|c|}{ Rainfall $^{1}$} \\
\hline & $0.82 b^{1}$ & $0.20 \mathrm{a}$ & $3.52 \mathrm{~b}$ & $0.6256 \mathrm{~b}$ & $0.39 \mathrm{~b}$ & $1.44 \mathrm{c}$ \\
\hline & \multicolumn{6}{|c|}{ Throughfall $^{1}$} \\
\hline Mangium & $1.29 \mathrm{a}^{*}$ & $0.24 \mathrm{a}$ & $31.85 \mathrm{a}$ & $1.05 \mathrm{a}$ & $1.00 \mathrm{a}$ & $5.67 \mathrm{a}$ \\
\hline Guachapele (G) & $1.55 \mathrm{a}$ & $0.22 \mathrm{a}$ & $15.77 \mathrm{~b}$ & $0.82 \mathrm{ab}$ & $1.32 \mathrm{a}$ & $4.00 \mathrm{~b}$ \\
\hline Eucalyptus (E) & $1.38 \mathrm{a}$ & $0.33 \mathrm{a}$ & $14.83 \mathrm{~b}$ & $0.94 \mathrm{ab}$ & $0.96 \mathrm{a}$ & $3.78 \mathrm{~b}$ \\
\hline \multirow[t]{2}{*}{ Mixed crop $(\mathrm{G}+\mathrm{E})$} & $1.36 \mathrm{a}$ & $0.26 \mathrm{a}$ & $8.89 \mathrm{~b}$ & $1.16 \mathrm{a}$ & $1.16 \mathrm{a}$ & $2.90 \mathrm{bc}$ \\
\hline & \multicolumn{6}{|c|}{ Stemflow } \\
\hline Species & $\mathrm{N}-\mathrm{NH}_{4}^{+}$ & $\mathrm{P}$ & $\mathrm{K}^{+}$ & $\mathrm{Ca}^{+2}$ & $\mathrm{Mg}^{+2}$ & $\mathrm{Na}^{+2}$ \\
\hline Mangium & $1,41 \mathrm{ab}^{*}$ & 0,46 a & $30,45 \mathrm{bc}$ & $0,70 \mathrm{c}$ & $0,91 \mathrm{~b}$ & $4,87 \mathrm{c}$ \\
\hline Guachapele & $2,28 \mathrm{a}$ & $0,73 \mathrm{ab}$ & $66,39 \mathrm{ab}$ & $0,50 \mathrm{c}$ & $1,16 \mathrm{~b}$ & $8,80 \mathrm{~b}$ \\
\hline Eucalyptus & $0,25 \mathrm{c}$ & $1,07 \mathrm{a}$ & 90,5 a & $11,73 \mathrm{a}$ & $7,10 \mathrm{a}$ & $13,08 \mathrm{a}$ \\
\hline Guachapele mixed & $2,28 \mathrm{a}$ & $0,40 \mathrm{~b}$ & $14,17 \mathrm{c}$ & $0,75 \mathrm{c}$ & $1,42 \mathrm{~b}$ & $2,73 \mathrm{c}$ \\
\hline Eucalyptus mixed & $0,78 \mathrm{bc}$ & $1,20 \mathrm{a}$ & 49,44 abc & $7,36 \mathrm{~b}$ & $8,55 \mathrm{a}$ & $9,80 \mathrm{ab}$ \\
\hline
\end{tabular}

${ }^{1}$ Means of 12 replicates biweekly sampled; ${ }^{2}$ Means of 11 replicates biweekly sampled * Means values within the same column (but for each compartment) followed by the same letter are not significantly different by the Tukey test $(\mathrm{P} \leq 0,05)$. 
Table 3 - Amount of $\left(\mathrm{kg} \mathrm{ha}^{-1}\right)$ of $\mathrm{N}-\mathrm{NH}_{4}^{+}, \mathrm{P}, \mathrm{K}^{+}, \mathrm{Ca}^{+2}, \mathrm{Mg}^{+2}$ and $\mathrm{Na}^{+}$that reached the soil by incident rainfall (RF) and by stemflow (SF) or throughfall (TF) for each plantation and percentage values for the contribution of each compartment evaluated

Quadro 3-Quantidade de $\left(\mathrm{kg} \mathrm{ha}^{-1}\right) \mathrm{N}-\mathrm{NH}_{4}^{+}, \mathrm{P}, \mathrm{K}^{+}, \mathrm{Ca}^{+2}, \mathrm{Mg}^{+2}$ and $\mathrm{Na}^{+}$aportado ao solo via precipitação incidente (RF), escoamento pelo tronco $(S F)$ e precipitação interna $(T F)$ e porcentual da contribuição de cada compartimento

\begin{tabular}{|c|c|c|c|c|c|c|}
\hline Compartment/plantation $^{1}$ & $\mathrm{~N}-\mathrm{NH}_{4}^{+}$ & $\mathrm{P}$ & $\mathrm{K}^{+}$ & $\mathrm{Ca}^{+2}$ & $\mathrm{Mg}^{+2}$ & $\mathrm{Na}^{+}$ \\
\hline $\mathrm{RF}\left(\mathrm{kg} \cdot \mathrm{ha}^{-1}\right)^{*}$ & 5,02 & 0,57 & 11,35 & 4,02 & 2,82 & 5,19 \\
\hline $\mathrm{RF}\left(\mathrm{kg} \cdot \mathrm{ha}^{-1} \cdot \text { year }^{-1}\right)^{* *}$ & 8.42 & 0.95 & 19.04 & 6.74 & 4.72 & 8.71 \\
\hline TF- mang. $\left(\mathrm{kg} \cdot \mathrm{ha}^{-1}\right)^{* *}$ & 7.51 & 1.29 & 92.32 & 5.86 & 5.03 & 27.63 \\
\hline$(\%)$ & 67,33 & 41,89 & 59,58 & 78,84 & 72,43 & 66,56 \\
\hline $\mathrm{TF}$ - gua. $\left(\mathrm{kg} \cdot \mathrm{ha}^{-1}\right)^{* * *}$ & 13.32 & 1.54 & 137.34 & 6.72 & 8.77 & 27.75 \\
\hline$(\%)$ & 88,60 & 72,72 & 76,54 & 97,80 & 92,82 & 79,39 \\
\hline TF - euc. $\left(\mathrm{kg} \cdot \mathrm{ha}^{-1}\right)^{* * *}$ & 12.00 & 1.99 & 63.36 & 7.62 & 5.68 & 23.47 \\
\hline$(\%)$ & 99,42 & 75,17 & 73,68 & 62,21 & 61,45 & 78,75 \\
\hline $\mathrm{TF}-$ cons. $^{2}\left(\mathrm{~kg} \cdot \mathrm{ha}^{-1}\right)^{* *}$ & 12.37 & 1.43 & 39.05 & 11.77 & 10.06 & 20.15 \\
\hline$(\%)$ & 95,96 & 81,18 & 79,57 & 85,42 & 77,84 & 86,6 \\
\hline$\overline{\text { SF -mang. }\left({\left.\mathrm{kg} \cdot \mathrm{ha}^{-1}\right)^{* *}}^{*}\right.}$ & 3.64 & 1.79 & 62.64 & 1.57 & 1.91 & 13.88 \\
\hline$(\%)$ & 32,67 & 58,11 & 40,42 & 21,16 & 27,57 & 33,44 \\
\hline SF - gua. $\left(\mathrm{kg} \cdot \mathrm{ha}^{-1}\right)^{* *}$ & 1.71 & 0.58 & 42.09 & 0.15 & 0.68 & 7.20 \\
\hline$(\%)$ & 11,40 & 27,28 & 23,46 & 2,20 & 7,18 & 20,61 \\
\hline $\mathrm{SF}-$ euc. $\left(\mathrm{kg} \cdot \mathrm{ha}^{-1}\right)^{* * *}$ & 0.07 & 0.66 & 22.64 & 4.63 & 3.56 & 6.34 \\
\hline$(\%)$ & 0,58 & 24,83 & 26,32 & 37,79 & 38,55 & 21,25 \\
\hline $\mathrm{SF}-$ cons. $\left(\mathrm{kg} \cdot \mathrm{ha}^{-1}\right)^{* * *}$ & 0.52 & 0.33 & 10.03 & 2.01 & 2.87 & 3.12 \\
\hline$(\%)$ & 4,04 & 18,82 & 20,43 & 14,58 & 22,16 & 13,40 \\
\hline \multicolumn{7}{|l|}{ TOTAL $\left({\left.\mathrm{kg} \cdot \mathrm{ha}^{-1} \cdot \text { year }^{-1}\right)^{* * *}}\right.$} \\
\hline Mangium & 11.15 & 3.08 & 154.96 & 7.43 & 6.94 & 41.51 \\
\hline Guachapele & 15.03 & 2.12 & 176.43 & 6.87 & 9.45 & 34.95 \\
\hline Eucalipto & 12.07 & 2.65 & 86.00 & 12.25 & 9.24 & 29.81 \\
\hline Cons. Gua. + euc. & 12.89 & 1.76 & 49.53 & 13.78 & 12.93 & 23.27 \\
\hline
\end{tabular}

${ }^{*}$ Nutrient input by rainfall (from January $1^{\text {st }}$ to June $\left.15^{\text {th }}, 1998\right) ;^{* * *}$ Estimate based on corrections for the average mean annual precipitation; ${ }^{1}$ Treatments abbreviations: mang. - A. mangium, gua. - P. guachapele, euc. - E. grandis e cons. - P. guachapele + E. grandis; ${ }^{2}$ contribution of $P$. guachapele and E. grandis together.

The contribution of each species in mixed plantation, through stemflow, followed the same trend found in pure stands. Eucalyptus stemflow contributed with $53.4 \%$ of $\mathrm{N}^{-\mathrm{NH}_{4}^{+}}, 80.8 \%$ of $\mathrm{P}, 8.5 \%$ of $\mathrm{K}^{+}, 94.4 \%$ of $\mathrm{Ca}^{+2}$, $91.2 \%$ of $\mathrm{Mg}^{+2}$ and $84.9 \%$ of $\mathrm{Na}^{+}$. These values result from the eucalyptus dominance under guachapele (BALIEIRO et al., 2002) and thus its capacity to intercept rainfall.

The presence of guachapele in the mixed stand added $487 \mathrm{~g}$ of $\mathrm{N}-\mathrm{NH}_{4}{ }^{+}$, comparing with inputs from pure eucalyptus stands. This contribution is low compared to the litterfall (BALIEIRO et al., 2004) with both sources contributing with $\mathrm{N}$ to the mixed stand. Comparatively to pure stand of eucalyptus, the mixed plantation intensifies the $\mathrm{N}, \mathrm{Ca}$ and $\mathrm{Mg}$ leaching by the canopy, while the inputs of $\mathrm{K}$ and $\mathrm{P}$ were lower under this plantation. Balieiro et al. (2002) evaluated the nutrient balance for different cropping systems and concluded that to maintain the next crop productivity, considering the balance with soil and litter nutrients availability and that only the stem (without bark) would be harvested, the addition of only $\mathrm{K}$ and $\mathrm{P}$ would be required, since $\mathrm{N}$ may be added by $\mathrm{N}_{2}$ fixation.

The mixed plantations with a nitrogen-fixing tree may be the best alternative for forestry in the tropics, because it may improve nutrient availability and efficiency of use. In addition, multiple crops can also minimize diseases and insect pests, flooding, moderate local and regional climate and remove and store atmospheric carbon dioxide as organic matter in the soil and consequently reduce greenhouse effect.

The nutrient inputs under each plantation followed the nutrient concentration in each water sample analyzed (throughfall and stemflow), with higher inputs under guachapele plantation. However, it is important to point 
out the constant presence of guachapele small leaves in the pluviometers and collectors despite of the high frequency of sample collection and careful cleaning of collectors.

\section{CONCLUSIONS}

- Mangium showed intermediary contribution in nutrient contents, between eucalyptus and guachapele, however it diverted $33.4 \%$ of the incident rainfall to stemflow, denoting a higher competitive character in collecting water and total nutrients to its trunk;

- Comparatively to pure eucalyptus stand, the mixed crop intensified the $\mathrm{N}, \mathrm{Ca}$ and $\mathrm{Mg}$ leaching by the canopy, while the inputs of $\mathrm{K}$ and $\mathrm{P}$ were lower under this cropping system.

\section{ACKNOWLEDGMENTS}

The authors would like to thank CNPq and FAPERJ for the financial support, and Carlos Fernando da Cunha and Nélio Coutinho for their assistance during this work.

\section{REFERENCES}

ARCOVA, F.C.S.; CICCO, V.; ROCHA, P.A.B. Precipitação efetiva e interceptação das chuvas por floresta de Mata Atlântica em uma microbacia experimental em Cunha - São Paulo. Revista Árvore, v. 27, n. 2, p. 257-262, 2003.

ANDRADE, G.C. et al. Contribuición del agua de lluvia en la oferta de nutrientes minerales para Eucalyptus grandis. Bosque, v.16, n.1, p.47-51, 1995.

BALIEIRO, F.C.; CUNHA, C.F.; FRANCO, A.A. Coletor de água para avaliação do escorrimento em tronco de espécies arbóreas. Revista Árvore, v.25, n.2, p.167-173, 2001.

BALIEIRO, F.C. et al. Accumulation and distribution of aboveground biomass and nutrients under pure and mixed stands of Pseudosamanea guachapele Dugand e Eucalyptus grandis W. Hill ex Maiden. Journal of Plant Nutrition, v.24/25, p.2639-2654, 2002.

BALIEIRO, F. C. et al. Dinâmica da serapilheira e transferência de nitrogênio ao solo em plantios de Pseudosamanea guachapele e Eucalyptus grandis. Pesquisa Agropecuária Brasileria, v.39, n.6, p.597-601, 2004.
BINKLEY, D. et al. Production and nutrient cycling in mixed plantation of Eucalyptus and Albizia in Hawaii. Forest Science, v.38, p.393-408, 1992.

BROCKWELL, J. et al. Nitrogen fixation in Acacias: an untapped resourse for sustainable plantations, farm, forestry and land reclamation. Melbourne: CSIRO, 2005. 132p. (ACIAR Monograph, 115).

CALDER, I.R. Water use by forest, limits and controls. Tree Physiology, v. 18, n.8/9, p.625-631, 1998.

CARVALHO, C.N. Fluxo geoquímico de Na, K, Ca e Mg em função do uso agrícola. 1992. 306f. Tese (Doutorado em Solos e Nutrição de Plantas) - Universidade Federal do Rio de Janeiro, Rio de Janeiro, 1992.

DEFELIPO, B.V.; RIBEIRO, A.C. Análise química do solo (metodologia). Viçosa, MG: Universidade Federal de Viçosa, 1986. 17p. (Boletim de Extensão).

\section{EMPRESA BRASILEIRA DE PESQUISA} AGROPECUÁRIA - EMBRAPA. Centro Nacional de Pesquisa de Solos. Sistema Brasileiro de Classificação de Solos. Brasília: Embrapa Produção de Informação, Rio de Janeiro: Embrapa Solos, 1999. 412p.

EUCLYDES, R.F. Manual de utilização do programa SAEG (Sistema para análises estatísticas e genéticas). Viçosa-MG: Imprensa Universitária da UFV, 1983. 59p.

FORRESTER, D. et al. Mixed-species plantations of Eucalptus with nitrogen fixing trees: A review. Forest Ecology and Management, v.233, p.211-230, 2006.

FRANCO, A.A.; FARIA, S.M. The contribution of $\mathrm{N}_{2}$-fixing tree legumes to land reclamation and sustainability in the tropics. Soil Biology and Biochemistry, v.29, n.5/6, p.897-903, 1997.

GOLley, F.R. Ciclagem de minerais em um ecossistema de floresta úmida. São Paulo: EPU/USP, 1978. 256p.

R. Árvore, Viçosa-MG, v.31, n.2, p.339-346, 2007 
JORDAN, C.F. The nutrient balance of an amazonian rain forest. Ecology, v.63 n.3, p.647-654, 1982.

KEMPERS, A.J.; ZWEERS, A. Ammonium determination in soil extracts by the salicylate method. Communications In Soil Science and Plant Analysis, v.17, n.7, p.715-723, 1986.

KRAMER, P.J.; BOYER, J.S. Transpiration and the ascent of sap. In: Water Relations of Plant and Soils. San Diego: Academic Press, 1995. p.262-290.

KRÄMER, U. Phytoremediation: novel approaches to cleaning up polluted soils. Current Opinion in Biotechnology, v.16, p.133-141, 2005.

LACLAU, J.P. et al. Nutrient cycling in a clonal stand of Eucalyptus and an adjacent savanna ecossistem in Congo. 1. Chemical composition of the rainfall, througfall and the stemflow solutions. Forest Ecology and Managnement, v.176, n.1/3, p.105-119, 2003.

LEITE, F.P. et al. Relações hídricas em povoamento de eucalipto com diferentes densidades populacionais. Revista Brasileira de Ciência do Solo, v.23, n.1, p.9-16, 1999.

LIMA, W.P. Alteração do pH, condutividade e das concentrações de $\mathrm{Ca}, \mathrm{Mg}$ e $\mathrm{P}$ da água da chuva em floresta de Pinus caribaea Morelet var. caribaea. IPEF, v.18, p.37-54, 1979.

LIMA, W.P. Impacto ambiental do eucalipto. 2.ed. São Paulo: EDUSP, 1993. 301p.

McKNIGHT, T.L. Climatic zones and types. In: McKNight, T.L. Physical geography: a landscape appreciation. 5. ed. New Jersey: Prentice Hall, 1996. p: 202-241.
MARSHNER, H. Mineral nutrition of higher plants. San Diego: Academic Press, 1995. p.116-130.

MATTOS, C.C.L.; SILVA, M.A.R.; OLIVEIRA, M.N. COMBAT, I.B. Boletim Agrometeorológico.

Floresta e Ambiente, v.5, n.1, p.208-215, 1998.

NATIONAL RESEARCHCOUNCIL-NRC. Mangium and other fast-growing acacias for the humid tropics. Washington, D.C.: National Academic Press, 1983. 65p.

OPAKUNLE, J.S. Througfall, stemflow and rainfall interception in a cacao plantation in south western nigeria. Tropical Ecology, v.30, n.2, p.244-252, 1989.

PASSOS, R.; BALIEIRO, F.C.; CANTARUTTI, R.B. Determinação colorimétrica de amônio em extratos de solo pelo método do salicilato. In: FertBIO, 1., 1998.Caxambú-MG, Anais... Caxambú-MG: Universidade Federal de Lavras / Sociedade Brasileira de Ciência do Solo, 1998. 554p.

REICHARDT, K. A água em sistemas agrícolas. São Paulo: Mariole, 1990. 188p.

RESH, S.C.; BINKLEY, D.; PARROTA, J.A. Greater soil carbon sequestration under nitrogen-fixing trees compared with Eucalyptus species. Ecossystems, v.5, p.217-231, 2002.

SANFORD Jr., R.L. Apogeotropic roots in an Amazon rain forest. Science, v.235, p.1062-1064, 1987.

SILVA FILHO, E.V. Estudos da chuva ácida e de entrada de $\mathrm{Na}, \mathrm{K}, \mathrm{Ca}, \mathrm{Mg}$ e Cl na Baía do Alto Rio Cachoeira, Parque Nacional da Tijuca, RJ. 1985. 92f. Dissertação (Mestrado em Solos e Nutrição de Plantas) - Universidade Federal Fluminense, Rio de Janeiro, 1985. 